\title{
The Level of Malondialdehyde in People Exposed to Air Pollution
}

\author{
Aguscik, Ridwan Ikob, Sumitro Adi Putra \\ Nursing Science Program, Health Polytechnic of Palembang, Indonesia
}

\begin{abstract}
Article Info
Article history:

Received Dec 12, 2016

Revised Feb 02, 2017

Accepted Feb 12, 2017

\section{Keyword:}

Air Pollution

Hydrogen Sulfide

Oxidative Stress

ABSTRACT

Air pollution cannot be avoided by people especially those living in big cities. Rubber factories and landfill sites are two examples of activities that can trigger air pollution. $\mathrm{H}_{2} \mathrm{~S}$ gas produced from rubber factories and landfill sites can create unpleasant smells and air contamination and increase free radicals in environment. This study was to assess the level of oxidative stress in people living near rubber factories and landfill sites. This was crosssectional study involving 60 people as the study sample. The level of $\mathrm{H}_{2} \mathrm{~S}$ gas was measured to determine the presence of air pollution. Blood collected from vena mediana cubiti was drawn to determine the level of malondialdehyde (MDA) as a marker of oxidative stress. Data obtained from this study were analyzed using independent t-test. The levels of $\mathrm{H}_{2} \mathrm{~S}$ gas from landfill site were higher than those from rubber factory $(0.482 \mathrm{ppm}$ vs. $0.332 \mathrm{ppm})$. On the other hand, the average level of MDA in people living near the rubber factory was higher than that living near the landfill site $(0.847 \pm 0.269 \mathrm{nmol} / \mathrm{mL}$ vs $0.748 \pm 0.253 \mathrm{nmol} / \mathrm{mL})$. It was found no significant difference $(p<0.05)$ in the average levels of MDA between people living near the rubber factory and those living near the landfill site. There was no significant difference in the average levels of oxidative stress between people living near rubber factory and those living near landfill site.
\end{abstract}

Copyright (C) 2017 Institute of Advanced Engineering and Science. All rights reserved.

\section{Corresponding Author:}

Aguscik,

Health Polytechnic of Palembang, Nursing Science Program,

South Sumatera, Palembang, Indonesia.

Email: haguscik23@gmail.com

\section{INTRODUCTION}

Air pollution is one of the health problems faced by almost all countries all over the world. The high rate of urbanization throughout the world resulted in the high rate of emission produced by industries and vehicles. Nowadays $50 \%$ of people living in cities and urban areas are continually exposed to the air pollution [1]. Continuing exposure to air pollution will cause health problems. If it is inhaled, pollutant will enter circulation system and can make bad impact on various organs and systems [2].

One of the pollutants that play an important role in causing air pollution is hydrogen peroxide $\left(\mathrm{H}_{2} \mathrm{~S}\right)$ gas. $\mathrm{H}_{2} \mathrm{~S}$ is colorless gas, highly toxic, flammable, and has specific odor as smelled in decayed eggs. $\mathrm{H}_{2} \mathrm{~S}$ can come from landfill site and rubber factory. Ammonia $\left(\mathrm{NH}_{3}\right)$ and $\mathrm{H}_{2} \mathrm{~S}$ gases which were produced by garbage decomposition process will decrease the quality of air around the landfill site and the quality of ambient air as well [3]. These gases will give bad impact on health because $\mathrm{H}_{2} \mathrm{~S}$ gas can be rapidly absorbed by lungs. In lower concentration $\mathrm{H}_{2} \mathrm{~S}$ can cause irritations either on eyes, nose, or throat. Moreover, this gas can cause breathing difficulty on asthma sufferers [4].

The higher level of oxidant and pro-oxidant in environment exposed to air pollution will form oxygen and nitrogen of free radicals. Free radicals which were inhaled by respiratory tract, if not neutralized 
by body antioxidant, will lead to oxidative stress. Oxidative stress not only affects respiratory system but also make systemic effects [5]. Oxidative stress which is coming from air pollution can create inflammatory responses in respiratory tracts, blood vessels, and heart [6]. In addition, in molecular level oxidative stress can cause the destruction of protein, lipid, and macromolecules such as DNA and RNA [7]. A biomarker used to detect the presence of oxidative stress is malondialdehyde (MDA), a highly reactive compound and an end product of lipid peroxidation [8]. $\mathrm{H}_{2} \mathrm{~S}$ gas is one of the air pollutant gases that can come out from rubber factory and landfill site. Rubber processing and open dumping can produce $\mathrm{H}_{2} \mathrm{~S}$ that has unpleasant smells and contaminate the air. People who live near rubber factory and landfill site will be continually exposed to air pollution. However, there is no data regarding the level of $\mathrm{H}_{2} \mathrm{~S}$ in both areas and the effects of $\mathrm{H}_{2} \mathrm{~S}$ on oxidative stress level. Therefore, this study was to determine the level of $\mathrm{H}_{2} \mathrm{~S}$ in rubber factory and landfill site and the level of MDA as an indicator of oxidative stress in people living near Sukawinatan Landfill Site and Gandus Rubber Factory.

\section{RESEARCH METHOD}

This was cross-sectional study which was conducted from May to June 2016. The sample of study was 60 people domiciled near rubber factory in Gandus and landfill site in Sukawinatan. The inclusion criteria were those who had lived near the area being investigated for at least three years, healthy, aged 18-30 years old, non smokers and did not take anti-inflammatory drugs. The determination of $\mathrm{H}_{2} \mathrm{~S}$ level was conducted by laboratory staff of Enviromental Health Technique and Disease Control Centre (BTKL Palembang). Blood specimen for MDA level determination was collected from vena mediana cubiti and then sent to Laboratory of Bio Sains Riset Palembang. This study got its ethical clearance from Faculty of Medicine, Sriwijaya University.

\subsection{The Collection of $\mathrm{H}_{2} \mathrm{~S}$ Sample}

The collection of $\mathrm{H}_{2} \mathrm{~S}$ sample was taken in two sites i.e Gandus Rubber Factory and Sukawinatan Landfill Site. The sampling collection was taken in the distance of 250 meters using methylen blue method. The procedures of sampling collection were as follows.

a. Prepare midget impinger, flow meter, and air vacuum pump. Fill midget impinger with $25 \mathrm{ml}$ of absorbing solution and set the instruments in order: midget impinger, flow meter, and air vacuum pump.

b. Switch the pump on, record the debit and length of pumping. The length of the pumping was from around 5 minutes to 1 hour depending on the debit of pump and the sample of air. After sample collection was finished, the pump was switched off and the absorbing solution in midget impinger was taken out for $\mathrm{H}_{2} \mathrm{~S}$ level determination.

c. Sampling analysis

- Pour the absorbing solution from midget impinger into a volumetric flask of $25 \mathrm{ml}$. Set the volume into $25 \mathrm{ml}$ by adding absorbing solution.

- Add $0.6 \mathrm{ml}$ of amine solution and 2-3 drops of ferric chloride solution. Let it stand for 30 minutes.

- Measure the absorbance of blue color using spectrophotometer in the wavelength of $670 \mathrm{~nm}$.

- Find out the level of $\mathrm{H}_{2} \mathrm{~S}$ in sample in microgram using standard curve. Calculate the level of $\mathrm{H}_{2} \mathrm{~S}$ in air sample using the following formula:

$$
H_{2} \text { S level }=\frac{A m g / m^{\text {a }}}{Q x t}
$$

or

$$
H_{2} S \text { level }=\frac{A x f p p m}{Q x t}
$$

Legend: $\quad \mathrm{A}=$ the level of $\mathrm{H}_{2} \mathrm{~S}$ in solution (in microgram)

$\mathrm{Q}=$ pumping debit (1/minute)

$\mathrm{t}=$ the length of pumping (in minute)

$\mathrm{f}=$ conversion factor

\subsection{The Determination of Plasma MDA Level}

The determination of MDA level was conducted using TBARS method as described below:

a. Pipette $400 \mu \mathrm{l}$ of plasma into a test tube and add TCA $20 \% 200 \mathrm{ml}$. Mix with vortex.

b. Centrifugate for 10 minutes at $3500 \mathrm{rpm}$ 
c. Separate the supernatant into a new tube

d. Add $400 \mu$ l of TBA $0.67 \%$ and mix with vortex

e. Incubate for 10 minutes in incubator at $100^{\circ} \mathrm{C}$

Let it stand in room temperature and read the absorbance using spectrophotometer at $530 \mathrm{~nm}$.

\section{RESULTS AND ANALYSIS}

\subsection{The Level of $\mathrm{H}_{2} \mathrm{~S}$}

From the results of $\mathrm{H}_{2} \mathrm{~S}$ determination, it was found that the level of $\mathrm{H}_{2} \mathrm{~S}$ around Sukawinatan Landfill Site was higher than that around Gandus Rubber Factory. The details of results is shown in Table 1.

Table 1. The Level of $\mathrm{H}_{2} \mathrm{~S}$ in Gandus Rubber Factory and Sukawinatan Landfill Site

\begin{tabular}{ccc}
\hline Gandus Rubber Factory $(\mathrm{ppm})$ & Sukawinatan Landfill Site $(\mathrm{ppm})$ & Threshold Level $(\mathrm{ppm})$ \\
\hline 0.332 & 0.482 & 0.02 \\
\hline
\end{tabular}

Based on the results of study, it was found that the levels of $\mathrm{H}_{2} \mathrm{~S}$ in Gandus Rubber Factory and Sukawinatan Landfill Site were $0.332 \mathrm{ppm}$ and $0.482 \mathrm{ppm}$, respectively. These results were 16 and 24 times higher than the threshold level of $\mathrm{H}_{2} \mathrm{~S}$. The level of $\mathrm{H}_{2} \mathrm{~S}$ in Sukawinatan Landfill Site was higher than that in Gandus Rubber Factory. This might be assumed that garbage management system in Sukawinatan Landfill Site was open dumping.

Open dumping is common to use as waste disposal system in developing countries. This has something to do with the lack of finance for and trained human resources in waste disposal management. Open dumping is the disposal of waste in a location without given any special treatments. This open dumping system can contaminate environment in the form of air pollution. It is understood why the air around Sukawinatan Landfill Site was contaminated with $\mathrm{H}_{2} \mathrm{~S}$ and unpleasant smells. Open dumping can become the source of disease vector development (such as flies, mice, cockroaches), spread unpleasant odor, contaminate surrounding air and surface and ground water, trigger a fire hazard, and create prolonged heavy smoke of fire [9].

Because open dumping is highly potential in contaminating the environment, waste disposal system using open dumping must be located very far away from urban settlements and laid on a relatively wide land. Landfill site of Sukawinatan was originally located far away from downtown. Following the growing number of people, the area near the landfill site was gradually settled and much housing is developed. Based on the preliminary studies, it was found that at the beginning of settlement in Sukawinatan people felt annoyed with the air pollution. However, after settling in a long time people are accustomed to living with $\mathrm{H}_{2} \mathrm{~S}$ from air pollution.

Hydrogen sulfide is colorless gas, highly toxic, flammable, and has specific odor as found in decayed eggs. This pungent smell can be detected if the level of $\mathrm{H}_{2} \mathrm{~S}$ is $\geq 0.13 \mathrm{ppm}[10] . \mathrm{H}_{2} \mathrm{~S}$ at $0.05 \mathrm{ppm}$ can only spread its odor and at $0.1 \mathrm{ppm}$ causes irritations and lack of sensory taste. After being exposed to the level above $50 \mathrm{ppm}$, the symptoms will be gradually worse, painful conjunctivitis, headache, anosmia,


consciousness, breathing depression, and the individual will die in 30-60 minutes [11]. Hydrogen sulfide $\left(\mathrm{H}_{2} \mathrm{~S}\right)$ in landfill gas, formed with the biodegradation of municipal solid waste, is a major odorous component in a landfill. It poses a potential risk to humans and causes odor problems and complaints by the residents near landfills [12]. Recent studies have implicated that $\mathrm{H}_{2} \mathrm{~S}$ is involved in physiological and pathological processes of many diseases, including cardiovascular, respiratory, nervous and endocrine systems [13].

The results of this study are in line with those of Mardiani (2006). She found that the level of $\mathrm{H}_{2} \mathrm{~S}$ gas exceeded a threshold level in radius of 25 meters from landfill site [14]. In addition, a study of Meirinda (2008) indicated that $\mathrm{H}_{2} \mathrm{~S}$ level in landfill of Sampah Terjun Kecamatan Medan Marelan was above maximum level as regulated in a decree of environmental health ministry No. KEP-50/MENLH/11/1996 about Odor Standard [15]. The results of environmental impact analysis done in a landfill of Bantar Gebang Bekasi indicated that the air pollution occurred in the landfill was caused by the increase concentration of gases accompanied with unpleasant smells from activities done on the landfill such as demolition, hoarding, and pressing of rubbish [16]. 


\subsection{The Level of Plasma MDA}

The results of MDA level determination indicated that the average level of plasma MDA in people living near Gandus Rubber Factory was higher than that living near Sukawinatan Landfill Site. There was no significant difference $(\mathrm{p}<0.05)$ in the average level of plasma MDA between people living near Gandus Rubber Factory and those living near Sukawinatan Landfill Site as shown in Table 2.

Table 2. The Average Level of MDA in People Living Near Rubber Factory Compared with That in People Living Near Landfill Site

\begin{tabular}{ccc}
\hline $\begin{array}{c}\text { Gandus Rubber Factory } \\
\text { Mean } \pm \mathrm{SD}(\mathrm{nmol} / \mathrm{mL})\end{array}$ & $\begin{array}{c}\text { Sukawinatan Landfill Site } \\
\text { Mean } \pm \mathrm{SD}(\mathrm{nmol} / \mathrm{mL})\end{array}$ & $\mathrm{p}^{*}$ \\
\hline $0.847 \pm 0.269$ & $0.748 \pm 0.253$ & 0.143 \\
\hline $\mathrm{p}^{*}$ Mann-Withney Test $(\mathrm{p}<0.05)$ & &
\end{tabular}

The results of this study also revealed that there was no significant difference $(p<0.05)$ in the average level of MDA between people living near Gandus Rubber Factory and those living near Sukawinatan Landfill Site. The average level of MDA in people living near Gandus Rubber Factory was higher than those living near Sukawinatan Landfill Site. This was because most people living near the factory were the workers of Gandus Rubber Factory and they were exposed more to the air pollution than those living near Sukawinatan Landfill Site. Meanwhile, the occupation of people living near Sukawinatan Landfill Site was more variative. Their jobs were not only scavengers or janitors but also others. Some of them worked outside of Sukawinatan. Outdoor activities of people near Sukawinatan Landfill Site were more frequent than indoor ones so that the length of exposure to air pollution was shorter than those near Gandus Rubber Factory.

The imbalance between free radicals and antioxidants formed in the body resulted in the increase of MDA level as the biomarker of oxidative stress. This imbalance occurs when body is continuously exposed to highly polluted environment [17]. The environment with highly polluted air enhances body mechanism to fight for the toxicity. If body antioxidants cannot cope with this, the high level of free radicals will trigger the oxidative stress to occur and destruct lipid cell membranes, DNA, and protein. Several epidemiological studies revealed that long-term exposure significantly increase the biomarker of oxidative stress in blood. Oxidative stress caused by air pollution exposure may induce cellular damage that impacts on the respiratory and cardiovascular disorders [18].

According to Delfino et al, chemical components of air pollutant exposures that induce oxidative stress and subsequent inflammation may be partly responsible for associations of cardiovascular morbidity and mortality with airborne particulate matter and combustion-related pollutant gasses [17]. The mechanism of air pollution-induced health effects involves an inflammation-related cascade and oxidation stress both in lung, vascular, and heart tissue [19]. Inflammation is initially a protective mechanism which removes the injurious stimuli and produces reactive oxygen species (ROS) able to induce cell killing. In the early phase of inflammation, oxidant stress does not directly cause cell damage and can induce the transcription of stress defense genes including antioxidant genes. This preconditioning effect of ROS enhances the resistance against future inflammatory oxidant stress and promotes the initiation of tissue repair processes. Oxidation damage has been implicated in many degenerative and nondegenerative diseases, including cardiovascular and pulmonary diseases, diabetes, and Alzheimer disease [20].

\section{CONCLUSION}

The study found that the level of $\mathrm{H}_{2} \mathrm{~S}$ gas in landfill site was higher than that in rubber factory. However, there was no significant difference in the average levels of oxidative stress between people living near rubber factory and those living near landfill site.

\section{ACKNOWLEDGEMENTS}

The researchers are very grateful to Health Polytechnic of Palembang for its financial support to this study through Hibah Bersaing 2016.

\section{REFERENCES}

[1] S. S. Salvi and P. J. Barnes, "Chronic obstructive pulmonary disease in non-smokers," Lancet, vol/issue: 374(9691), pp. 733-43, 2009. 
[2] R. D. Brook, et al., "Particulate matter air pollution and cardiovascular disease: An update to the scientific statement from the American Heart Association," Circulation, vol/issue: 121(21), pp. 2331-78, 2010.

[3] S. G. Ballal, et al., "Bronchial asthma in two chemical fertilizer producing factories in eastern Saudi Arabia," Int JTuberc Lung Dis, vol. 2, pp. 330-335, 1998.

[4] USEPA, "Integrated Risk Information System toxicity summary for hydrogen sulfide," 2003.

[5] Künzli N., et al., "Air quality and health," Lausanne, European Respiratory Society, 2010.

[6] L. E. Wold, et al., "In vivo and in vitro models to test the hypothesis of particle-induced effects on cardiac function and arrhythmias," Cardiovascular Toxicology, vol/issue: 6(1), pp. 69-78, 2006.

[7] L. Risom, et al., "Oxidative stress-induced DNA damage by particulate air pollution," Mutation Research: Fundamental and Molecular Mechanisms of Mutagenesis, vol/issue: 592(1-2), pp. 119-137, 2005.

[8] I. Rahman, et al., "Oxidant and Antioxidant Balance in the Airways and Airway Diseases," Eur J Pharmacol, vol. 533, pp. 222-239, 2006.

[9] S. M. I, et al., "Open dumping of municipal solid waste and its hazardous impacts on soil and vegetation diversity at waste dumping sites of Islamabad city,” Journal of King Saud University-Science, vol. 26, pp. 59-65, 2014.

[10] Agency for Toxic Subtances and Disease Registry, "Draft Toxi- cological Profile For Hydrogen Sulfide And Carbonyl Sulfide, Atlanta, Georgia, Division Of Toxicology And Human Health Sciences,” Environmental Toxicology Branch, 2014.

[11] Ditjen PPM \& PL, "Parameter Pencemar Udara \& Dampaknya Terhadap Kesehatan Manusia," Departemen Kesehatan RI, Jakarta, 2001.

[12] Ko J. H., et al., "Emissions and Control of Hydrogen Sulfide at Landfills: A Review," Critical Reviews in Environmental Science and Technology, vol. 45, pp. 2043-83, 2015.

[13] Song Y. and Linlin W., "Hydrogen Sulfide and Acute Lung Injury," World Journal of Pharmacy and Pharmaceutical Sciences, vol. 5, pp. 367-86, 2016.

[14] E. Mardiani, "Correlation between Ambient Air Quality \& Vectors to Respiratory and Digestive Disorders around Landfill Site," Thesis, Airlangga University, 2006.

[15] Merinda, "Factor Correlated with In-Door Air Quality around Landfill Site in Kelurahan Terjun Kecamatan Medan Marelan,” Thesis, Postgraduate Program of North Sumatra University, Medan, 2008.

[16] N. Noriko, "Final Review of Landfill Site of Bantar Gebang Bekasi," Postgraduate Program, Bogor Agricultral Institute, 2003. Accessed on April 10, 2016.

[17] Delfino R. J., et al., "Air pollution and circulating biomarkers of oxidative stress," Air Qual Atmos Health, vol. 4, pp. 37-52, 2011.

[18] M. Lodovici and E. Bigagli, “Oxidative Stress and Air Pollution Exposure,” Journal of Toxicology, pp. 1-9, 2011.

[19] A. J. Ghio, et al., "Concentrated ambient air particles induce mild pulmonary inflammation in healthy human volunteers," American Journal of Respiratory and Critical Care Medicine, vol/issue: 162(3), pp. 981-988, 2001.

[20] H. Jaeschke, "Reactive oxygen and mechanisms of inflammatory liver injury: present concepts," Journal of Gastroenterology and Hepatology, vol/issue: 26(1), pp. 173-179, 2011. 